\section{B A Institute of \\ YK Business Administration \\ 六下 \\ Karachi \\ Leadership and Ideas for Tomorrow}

Business Review

Volume 9 Issue 1 January-June 2014

$1-1-2014$

\title{
Determinants of trade balance: A comparison between Pakistan and India
}

Khola Asif

Dadabhoy Institute of Higher Education

Aurangzeb -

Dadabhoy Institute of Higher Education

Follow this and additional works at: https://ir.iba.edu.pk/businessreview

Part of the Business Commons

(c) (;)

This work is licensed under a Creative Commons Attribution 4.0 International License.

\section{Recommended Citation}

Asif, K., \& -, A. (2014). Determinants of trade balance: A comparison between Pakistan and India. Business Review, 9(1), 33-46. Retrieved from https://doi.org/10.54784/1990-6587.1226

This article is brought to you by iRepository for open access under the Creative Commons Attribution 4.0 License and is available at https://ir.iba.edu.pk/businessreview/vol9/iss1/3. For more information, please contact irepository@iba.edu.pk. 


\title{
ARTICLE
}

\section{Determinants of Trade Balance: A Comparison between Pakistan and India}

\author{
Aurangzeb \\ Dadabhoy Institute of Higher Education \\ Khola Asif
}

\section{Abstract}

This study investigates and compares the determinants of the trade balances of Pakistan and India. In this research the impact of gross domestic product (GDP), foreign direct investment (FDI), exchange rate (ER) and the remittances on the trade balance of India and Pakistan have also been considered. For this, time series data from 1981 to 2010 is used. The results of the study are based on the regression analysis, and granger causality test. Regression analysis showed that the GDP of India and Pakistan both have significant positive impact on the balance of the trade, FDI has significant negative impact on $T B$ of Pakistan and significant positive impact on the TB of India, this negative relation in case of Pakistan is due to multiple reasons, such as security concerns, political unrest, the different wars, corruption and improper utilization of labor and capital. ER has significant negative impact on both India and Pakistan's TB and remittances have significant negative impact for Pakistan and significant positive impact for the TB of India. Granger causality result showed bidirectional causal relation in Indian model, and unidirectional causal relation in Pakistani model.

The outcome recommends that local currency needs to be stronger in order to improve the trade balance of both the countries, also for Pakistan a more comprehensive research is required in order to identify the factors which are responsible for the negative effect of both FDI and Remittances on the trade balance.

Key words: Trade Balance, Regression, Remittances, Exchange Rate, FDI, Granger Causality.

\section{Introduction}

The trade balance is a measure that reflects the competitive strength of a country, the lower the trade deficit, the country have the greater competitive strength and has more rapid growth of the economy ${ }^{1}$. International trade, economics and economic growth are manipulated greatly by the global trends of trade movement and policies ${ }^{2}$. Too many factors are there which are affecting the trade balance of a country. Most of them had been studied in

\footnotetext{
${ }^{1}$ Trade deficit: Causes and Consequences by Gould and Ruffin (1996)

${ }^{2}$ Mohamad (2010)
} 
past. The majority of the past studies ${ }^{3}$ have focused on the factors that are affecting the trade balances of different countries individually, whereas this study is a comparison between the determinants of the trade balances of Pakistan and India.

At the time of independence, a small number of industries were inherited by Pakistan because of which Import Substitution Industrialization (ISI) strategy was implemented by government. To persuade export, Export Bonus Scheme (EBS) was established by government in 1960's. Most of the countries that have large trade surpluses, also have negative investment situation ${ }^{4}$. Trade deficit by most of the people is understood as a bad condition but it is not that bad. Sometimes economies need to reduce the value of their domestic currency (devaluation) to improve their exports. Many studies have explored that devaluation develops the balance of trade in long run and provide competitive advantage ${ }^{5}$.

A large number of industrialized countries are facing the deficits in the trade like United States of America (USA), Portugal, United Kingdom, Australia etc ${ }^{6}$. Pakistan is going through the phase of trade deficit since independence except three years which are 19471948, 1950-1951, and 1972-1973, India is also facing the trade deficit since 1947 except two years, 1972-1973, and 1976-1977 and deficits are increasing day by day. The continuous deficit in trade is not good for developing economies like Pakistan and India.

\section{Background}

Like an engine of growth, trade has performed essential role at different stages of development for countries. Imbalances in the trade are acknowledged as the trade deficit or trade surplus. The trade balance demonstrates improvement by a reduction in exchange rates.

Pakistan is facing the trade deficit since 1947 except three years. In 1947-1948, Pakistan had a surplus of Rs. 125 million, and the reason was high amount of export. The trade surplus of Pakistan in 1950-1951 was Rs. 176 million, and the reason was the excess export of the cotton and jute from East Pakistan (Bangladesh) and the reason of excess export was the Korean War. The reason of surplus in 1971-1972 was the devaluation of the currency (Pak Rupees) from Rs. 4.76 to Rs. 11 per dollar. The amount of surplus in 1972 was Rs. 124 million ${ }^{7}$.

Pakistan is majorly an agricultural base country with major exports of rice and raw cotton. A major reason of trade deficit in Pakistan is that high amount of food grains and food items are being imported due to mounting population. Another reason of deficit is the reduction in foreign investment because of terrorist activities and worsening law and order situations in Pakistan. Along with foreign investors, the law and order situations and political instability are discouraging local investors too.

Import and export of Pakistan with India were considerable for many years after independence, attaining 30 percent export and 10 percent of the imports. After some time,

\footnotetext{
${ }^{3}$ Ray (2012), Awan et al, (2011), Mohamad (2010), Rehman \& Uddin (2009), Zhung et al, (2007), Duasa (2007)

${ }^{4}$ Falk (2008) inflow of FDI is less than the outflow FDI

${ }^{5}$ Mohammad and Hosain (2010), Falk (2008), Mohammad (2010).

${ }^{6}$ Falk (2008)

${ }^{7}$ All values have been gathered from the state bank of Pakistan and economic survey of Pakistan.
} 
both reduced to an average of below five percent. After two decades in 1990's the amount of trade improved and the average amount almost doubled. But still, the quantity of trade between two countries is very low as compared to their potentials ${ }^{8}$.

\section{Research Objective}

The primary objective of this research is to conduct a comparative study of determinants of trade balance between India and Pakistan. The main objective of this study is to analyze the relationship between the gross domestic product, trade balance, foreign direct investment, remittances and exchange rate. And to find out that the variables which influence the trade balance of Pakistan, either they also affect the trade balance of India or not. This study is going to refine the previous studies and will present new interpretation about the factors effecting trade balance of Pakistan in comparison with India.

\section{Literature Review}

\section{Theoretical Background}

The divergence between the fiscal value of exports and imports of a country over a definite time period is known as the trade balance. If the imports of a country are more than the export of the country, it is called trade deficit and if imports are less than exports it's called as trade surplus. It is one of the leading sections of any balance of payments of a country. Foreign aid, Import, domestic spending abroad, and domestic investment abroad are the stuff of debit side of trade balance and the credit side of trade balance includes foreign spending in the domestic economy, export, and foreign investment in domestic economy. Trade balance shows only the trade of visible things or we can say merchandise ${ }^{9}$.

Trade deficit refers to the imbalances of debit and credit side of the balance of payments. It is a condition where out flow of domestic currency is more than the inflow of foreign currency in an economy. The trade balance shows improvement with depreciation in real exchange rate; however responsiveness of trade balance to the movement in exchange rate is low for those countries who's trade balance is negative or have a positive net foreign direct investment with huge amount ${ }^{10}$. The higher trade deficit could be attributed to a rise in petroleum, oil, and lubricants as well as non-petroleum, oil and lubricants components in imports $^{11}$.

Exchange rate is a very important factor which influence in examining a country's trade balance. It is the price/rate, upon which one country's currency can be expressed in another currency. It plays a very important role in making policies. It helps in determining of the trade flows, FDI, inflation, international reserve and remittances of a country. Theoretically, there is a positive significant relation between exchange rates (ER), and the trade balance of a country. A fall in the real effective exchange rate shows that the cost of goods manufactured domestically is reduced and as result competitiveness in export has boosted $^{12}$.

\footnotetext{
${ }^{8}$ State Bank of Pakistan

${ }^{9}$ Modern Economy Theory by K. K. Dewett (2005)

${ }^{10}$ Falk (2008)

${ }^{11}$ Ray (2012)

${ }^{12}$ Falk (2008), trade balance and real effective exchange rate in Malaysia By Dr. Mohammad B. Yusoff, Aziz (2008)
} 
Further considerable variables which influence the balance of trade are inflow of foreign cash through foreign direct investment (FDI) and the remittances. Foreign direct investment (FDI) is a measure that tells the foreign possession of assets like land, mines, and factories in a country. Theoretically foreign direct investment (FDI) has two types, inward and outward remittances. The remaining of these remittances (may be positive or negative) is called net FDI. To speed up socio-economic development, FDI is a very strong and important mechanism. An increase in FDI leads to increase in manufacturing import substitution products locally, which as a result reduce imports and improves the balance of trade ${ }^{13}$.

Worker's Remittance is a transfer of money to family members in home country from international migrants. For developing countries, it is one of the major sources of financial flows ${ }^{14}$. For Pakistan, in fiscal year 2010-2011, percentage change in Remittances was $17.72 \%$ and this percentage increased to $21.54 \%$ in 2011 - 2012 at amount of $\$ 7,435.98$. According to World Bank, in 2011 the amount of remittances to home countries will reach $\$ 353$ billion for developing countries and \$483 billion for overall world. In developing countries, India is on the top of the list with $\$ 58$ billion.

Gross domestic product (GDP) is an indicator which shows the health of an economy. It is the market value of all final goods and services produced in a country within a year. Gross domestic product (GDP) is a measure of national income. There are three approaches to calculate GDP 1) income method, 2) output method and 3) expenditure method. GDP of Pakistan is worth 175 billion or $0.28 \%$ of the world economy ${ }^{15}$.

\section{Empirical Studies}

Ray (2012) analyzed the role of FDI, real effective exchange rate, domestic consumption, and foreign income on long and short run behavior of trade balance in India. For sample data collected covering period 1972 to 1973 and 2010 to 2011. Statistical techniques OLS regression, augmented dickey fuller test, Johansen co integration test, and VECM are tested on sample data. The results showed that long and short run causality do exist between variables. There is a significant positive impact of FDI and foreign income on trade balance while domestic consumption and real effective exchange rate have a significant negative impact on trade balance of India.

Awan et al, (2011), analyzed the impact of fiscal deficit, exchange rate, and terms of trade on the external debt of Pakistan. The main objective of the study was to investigate the association between exchange rate, external debt, deterioration of terms of trade, and fiscal deficit. For sample, secondary data was collected covering period from 1974 to 2008. Unit root test, co integration, and Vector Error Correction Model (VECM) tests were applied on sample data. Four variables selected for the research are consolidated fiscal deficit, external debt, terms of trade and nominal exchange rate. The results showed that there is a long term significant relationship between exchange rate, external debt and deterioration of terms of trade and insignificant impact of fiscal deficit on external debt. They recommend that the government of Pakistan should not follow aid strictly and must follow the policy of trade. Consistency of Exchange Rate (ER) is essential to reduce the undesirable results because of external debt.

\footnotetext{
${ }^{13}$ Ray (2012)

${ }^{14}$ Do worker remittances promote economic growth? By Barajas et al, (2009)

${ }^{15}$ All figures have been taken from State bank of Pakistan
} 
Waliullah et al, (2010), investigated the short run and long run relation among the income, trade balance, real exchange rate, and money supply for Pakistan. For this purpose, annual data from 1970 to 2005 was collected. Statistical techniques error correction model and cointegration were tested on sample data. The results showed long term, steady relation among the income, trade balance, real exchange rate, and money supply. Further they explored that a strong role is played by money supply and income in determining behavior of trade balance. They recommended that by using policies for income and money supply, complication of trade balance should be reduced.

Shahbaz et al, (2010) examined the relationship among changes in the trade balance indicators of Pakistan and real exchange rate. For sample, quarterly data covering period from 1980 to 2006 was collected. Co integration, unit root test and auto regressive distributed lag (ARDL) techniques were tested on sample data. The variables used in the research were effective exchange rate (fixed), trade balance, floating exchange rates, and terms of trade. The results showed a significant positive relationship among the trade balance, real exchange rate, and trade balance, and significant negative relation between currency depreciation and trade balance. They suggested that import substitution policy must be introduced to reduce addiction of import.

Mohammad \& Hussain (2010) examined the effects of exchange rate depreciation on trade balance of Pakistan and for this purpose sample data from 1970 to 2008 was collected. Statistical technique, Johansson co-integration test, OLS regression, and augmented dickey fuller test were applied on the data. The variables used in the research were balance of trade, real effective exchange rate, domestic GDP (gross domestic product), and gross domestic product of the World (world industrial index). The result showed long term positive relationship between real effective exchange rate, real income, trade balance and negative relation with real domestic income. They recommended that exchange rate depreciation has a positive impact on trade balance and is in favor of the export of Pakistan.

Mohammad (2010) analyzed the long and short term determinants of trade deficit of Pakistan. For this, sample data covering period 1975 to 2008 was collected. Johansen co integration and vector error correlation model (VECM) techniques were applied on the data. The five variables selected for study were foreign direct investment (FDI), trade balance (TB), foreign income, real effective exchange rate (REER) and domestic consumption (DC). The results explored that there is a significant positive affect of domestic household consumption, real effective exchange rate (REER) and foreign investment (FI), on the trade deficit. They recommended that Pakistan government need to focus on subsidization like many other countries. And also need to sort out problems of SME's because they are playing a significant role in Pakistan's export.

Falk (2008) examined the factors affecting the aggregate trade balance in industrialized countries. For this, panel data of 32 economies were collected from period 1990 to 2007. The variables used in the study were real effective exchange rate, trade balance, GDP per capita, real domestic, foreign direct investment, and foreign income. The results were gained by using fixed effects model and linear mixed models. The result explored that a significant positive relation exist between the government budget balance and the TB (trade balance). A significant positive relationship was found between trade balance and real foreign GDP of trading partners and a negative relation between real domestic GDP and trade balance. The trade balance shows improvement with depreciation in real exchange rate; 
however the sensitivity of trade balance is minor for countries with a negative trade balance and/or a large positive net foreign direct investment.

Duasa (2007) studied the relationship among trade balance, real exchange rate, income, and money supply in Malaysian economy. For sample purpose, annual data was collected from period 1974 to 2003. The techniques Co integration and error correction modeling was tested on data. The variables selected for the study were real effective exchange rate (REER), gross domestic product (GDP), income and money supply, and the trade balances. The results are estimated, additional assumptions are presumed using variance decomposition and impulse response functions (IFR). The results discover long term relation between trade balance, income and money supply. And between real effective exchange rate (REER) and trade balance, no long term relation was found. They suggested that the monetary approaches should be used for Malaysian trade balance rather than exchange rate regime.

Zhung et al, (2007) explored that these are reasons of growing US trade deficit in consumer oriented agricultural products. For this purpose 16 years panel data covering period of 1989 to 2005 is selected from 28 different countries. The variables used in their research are FDI, CPI, population, total trade and total GDP. Generalized Least Square, and unit root test were applied on sample data. The results showed that per capita income in US is very important for the growing US trade deficit. A negative effect of US FDI overseas and exchange rate has seen on the US trade balance. They suggested that to improve the US trade balance, a raise in per capita income and trade liberalization is required.

Babar (2006) studied that imports of intermediate and capital goods have vital contribution in the export production of Pakistan. For sample, annual data covering period 1973 to 2005 was collected and ordinary least square technique was applied. The variables selected for the study were quantum index of export, capital imports, index of imports, relative price index, industrial raw material imports, nominal effective exchange rate, USA domestic output index and cotton production index. The results showed a significant long term relationship among exports and imports of intermediate and capital goods. They suggested that policy makers must put spotlight on importing those items that are directly used in export production.

Stucka (2004), analyzed impact of change in exchange rate on the trade balance in Croatia and for this purpose long and short run effects were estimated. For sample, quarterly data collected covered period from 1994 to 2002. Co-integration, Augmented Dickey-fuller (ADF) test, and unit root test were applied on the selected data. The five variables used in the research are trade balance, domestic GDP, foreign GDP, real effective exchange rate, real effective exchange rate PPI, and CPI. In result, the F-statistics and Wald test's significance showed co integration between variables. They suggested that after a permanent devaluation/depreciation, progress of the trade balance is very narrow.

Grube \& Samanta (2003), examined the impact of uncertainty of exchange rate on Mexican foreign trade and for this purpose sample data collected for time period 1980 to 2000. Auto-regression, unit root test, augmented dickey fuller test and t-statistics are tested on sample data. The variables used in their research are exchange rate, Mexican export, and real gross domestic product of United States. The results showed that negative relation among exchange rate (ER) and other economic factors of the Mexican economy. They recommended 
that Mexico should take advantage of its export potential and increase binding with US and other trading partners.

Lal \& Lowinger (2002), analyzed the short term and long term determinants of trade balance of five south Asian countries. For this purpose quarterly data was collected covering period 1985 to 1998. Augment Dickey-Fuller (ADF) test, Unit root test, Co-integration and error correction model was tested on the selected sample. The variables used are trade balance, nominal effective exchange rate, foreign exchange reserve of country, and real GDP. The results showed that the long and short run association does exist relating trade balances and nominal effective exchange rate.

Calderon et al, (1999), studied the determinants of current account deficit for developing countries and for sample, panel data of 44 developing countries for the time period 1966 to 1995 was collected. Regression analysis and correlation was tested on the sample data. The variables selected for the study were persistence, domestic growth rate, industrialized output growth rate, private and public saving rates, export, black market premium on foreign exchange, terms of trade, BOP restrictions, real exchange rate (RER), and real interest rate. The results explored that there is reasonable consistency in current accounts, a large current account deficit is generated by rise in domestic output growth, there is a positive impact of temporary increase in both public and private savings on current account, and the current account deficit is reduced in developing by both, either high rate in industrialized economies or large international interest rates.

Prasad \& Gable, (1997) analyzed the association between the international trade and the fluctuations of macroeconomic variables in industrial economies. Quarterly the data from period 1970 to 1995 was gathered as sample period. Vector auto-regression models were tested on the data. Variables selected for the study were real export, real import, trade balance, real GDP, and nominal and real effective exchange rates (REER). The result showed that trade balance improves in short run by monetary expansions. They concluded that various macroeconomic variable's fluctuations can affect the dynamics of international business trade in different ways.

\section{Methodology}

The research approach used for this study is quantitative. This approach is generally used to inspect the research questions and tests the theory ${ }^{16}$. The research design of this study is co-relational. In co-relational research, the variables are inspected in their natural environment and it doesn't encompass healings that are enforced by the researcher. It is exercised to inspect the relationship between two or more variables ${ }^{17}$.

The source of data is secondary. There are three main sites from where the data of India and Pakistan has been collected. The data of Pakistan has been gathered from the State Bank of Pakistan ${ }^{18}$ and the World Bank ${ }^{19}$ and Indian data has been collected from the web site of the World Bank and Economic Surrey of India 2010-2011. For sample, annual time series data of Pakistan and India is collected. The period 1981 to 2010 has been collected and used as sample period. OLS regression has been used for this research. It is a kind of

\footnotetext{
${ }^{16}$ James Neill (2003)

${ }^{17}$ Owen Emlen 2006

${ }^{18}$ www.sbp.org/pk

${ }^{19}$ www.worldbank.org
} 
technique that is used to identify with relationship between the dependent and independent (explanatory) variables. It explains that, how a change in one independent variable influences the dependent variable ${ }^{20}$.

Model

$$
\begin{aligned}
& T B_{\text {Pak }}=\alpha_{0}+\alpha_{1} G D P+\alpha_{2} E R+\alpha_{3} F D I+\alpha_{4} R E M+\varepsilon \\
& T B_{\text {Ind }}=\alpha_{0}+\alpha_{1} G D P+\alpha_{2} E R+\alpha_{3} F D I+\alpha_{4} R E M+\varepsilon
\end{aligned}
$$

Whereas; TB Pak is Trade balance of Pakistan, $\mathrm{TB}_{\text {Ind }}$ is Trade balance of India, ER is exchange rates, FDI is Foreign direct investment, GDP is Gross domestic products, and REM is Remittances.

\section{Data Analysis}

The foremost component of the research is analysis and its interpretation. This research has two models to test. First model is of Pakistan and the other model is to test Indian data. Regression analysis is applied for testing the relationship and the results are explained below. The study is done to divulge the relationship between the GDP, trade balance, FDI, exchange rate, and Remittances for India and Pakistan. Independent analysis will be executed to discover the impact of all the variables on the trade balances of India and Pakistan.

\section{Summary Statistics}

The descriptive statistics of data of determinants of the trade balance of Pakistan has been defined below in the table of descriptive statistics.

Table 4.1.1 Descriptive statistics

\begin{tabular}{|l|l|l|l|l|l|l|l|l|}
\hline \multirow{2}{*}{ Variables } & \multicolumn{4}{|l|}{ Model of TB } & \multicolumn{4}{l|}{ Model of TB } \\
\cline { 2 - 9 } & Mean & Max & Min & Std. Dev. & Mean & Max & Min & Std. Dev. \\
\hline \multirow{2}{*}{ Constant } & 0.957 & 2.06 & 0.03 & 0.505 & 0.452 & 1.18 & -0.53 & 0.371 \\
\hline GDP & 523.9 & 1727 & 190.5 & 398.6 & 70.85 & 176.9 & 28.1 & 43.74 \\
\hline FDI & 0.274 & 1.63 & -1.52 & 0.707 & -0.13 & 0.59 & -0.99 & 0.365 \\
\hline REMI & 0.884 & 1.73 & 0.35 & 0.476 & 0.396 & 0.99 & 0 & 0.266 \\
\hline ER & 1.425 & 1.69 & 0.94 & 0.26 & 39.31 & 58.19 & 9.9 & 22.33 \\
\hline
\end{tabular}

To find out the basic properties of the data, the descriptive statistics are used. Maximum and minimum show the ranges of variables, and the range of trade balances of Pakistan is between 0.03 and 2.06. Standard deviation describes the deviation of a variable from its mean.

${ }^{20}$ Multivariate Data Analysis $7^{\text {th }}$ ed. by Joseph, William, Barry and Rolph 


\subsubsection{Parameter estimates for TB}

\begin{tabular}{|c|c|c|c|c|c|c|}
\hline \multirow[b]{2}{*}{ Variables } & \multicolumn{3}{|c|}{ Model of $\mathbf{T B}_{\mathrm{PAK}}$} & \multicolumn{3}{|c|}{ Model of $\mathbf{T B}_{\text {IND }}$} \\
\hline & Coefficient & t-stats & Prob. & Coefficient & t-stats & Prob. \\
\hline Constant & 0.263 & 2.629 & 0.014 & 1.666 & 6.162 & 0.000 \\
\hline GDP & 0.026 & 8.497 & 0.000 & 0.001 & 2.663 & 0.013 \\
\hline FDI & -0.250 & -1.720 & 0.098 & 0.281 & 3.499 & 0.002 \\
\hline REMI & -0.720 & -3.230 & 0.003 & 0.583 & 2.141 & 0.042 \\
\hline ER & -0.040 & -8.860 & 0.000 & -1.12 & -3.970 & 0.001 \\
\hline Adj. $\mathbf{R}^{2}$ & \multicolumn{3}{|l|}{0.801} & \multicolumn{3}{|l|}{0.903} \\
\hline D-W stats & \multicolumn{3}{|l|}{1.805} & \multicolumn{3}{|l|}{1.801} \\
\hline $\begin{array}{l}\text { F-stats } \\
\text { (prob) }\end{array}$ & \multicolumn{3}{|l|}{$\begin{array}{c}30.219 \\
(0.000)\end{array}$} & \multicolumn{3}{|l|}{$\begin{array}{l}68.212 \\
(0.000)\end{array}$} \\
\hline
\end{tabular}

Source: Authors' Estimations.

For Pakistani model, the value of adjusted $\mathrm{R}^{2}$ showed that this model is $80.10 \%$ accurate and significant with $\mathrm{p}$ value 0.000 . It means that a healthy amount of change in trade balance is predicted by the GDP, FDI, ER, and Remittances.. The F-static of this model is 30.219 with p-value 0.00 which is smaller than 0.10 which means all the independent variables are good predictor of the dependent variable.

The constant value, also referred as the $\mathrm{Y}$ intercept, is 0.263 which shows the altitude of the regression line when it touches the $\mathrm{Y}$ axis. It is the forecasted value of Trade Balance where all the regressors are 0 . The results explain that GDP has significant positive impact on trade balance which is consistent with the theory that when economy grows, trade balance is improved as well. Result of FDI shows that it has a significant negative impact on the trade balance of Pakistan ${ }^{21}$, which means that when FDI increases, it worsens the trade balance. Negative FDI shows that to utilize FDI in productive manner we have to import heavy machineries and other things because of this, our balance goes into deficit.

Remittances show significant negative impact on the trade balance of Pakistan ${ }^{22}$ which represents that an increase in remittances leads to worsen the trade balance of Pakistani economy ${ }^{23}$, remittances have negative impact because although a big amount of remittances is received but these remittances are not been utilized in productive manner.The exchange rate

\footnotetext{
${ }^{21}$ Khan \& Hossain, (2010), Mohammad (2010), Falk (2008), Zhung et al, (2007)

${ }^{22}$ Zhung et al, (2007)

${ }^{23}$ Remittances and Reverse Flows in Developing Countries by Anupam Das and John Serieux 2010, The Jordanian Workers' Remittances Impact on the Main Macroeconomic Variablesby Jihad and Suleiman 2010.
} 
showed a significant negative impact in the trade balance. It means that when ER increases TB moves towards deficit and the trade balance moves towards surplus when exchange rate decreases (other variables remain constant).

$$
\begin{aligned}
& T B_{P a k}=\alpha_{0}+\alpha_{1} G D P+\alpha_{2} E R+\alpha_{3} F D I+\alpha_{4} R E M+\varepsilon \\
T B_{\text {Pak }}= & 0.263+0.026 G D P-0.035 E R-0.249 F D I-0.717 R E M+\varepsilon
\end{aligned}
$$

The second model that is of Indian data The model is $90.3 \%$ accurate and is significant with $\mathrm{p}$ value 0.000 . It means that a healthy amount of change in trade balance is predicted by the GDP, FDI, ER, and Remittances. The outcome explored that the GDP has significant positive impact on the trade balance of India which indicates that a growth in economy leads towards the improvement in trade balance too. Furthermore, FDI has significant positive relation with the trade balance that is steady with the previous studies ${ }^{24}$. Remittances show significant positive impact on the trade balance of India and the exchange rate showed significant negative relation with the trade balance of India which denotes that increases in the exchange rate direct towards the imbalances in trade.

$$
\begin{gathered}
T B_{\text {Ind }}=\alpha_{0}+\alpha_{1} G D P+\alpha_{2} E R+\alpha_{3} F D I+\alpha_{4} R E M+\varepsilon \\
T B_{\text {Ind }}=1.666+0.001 G D P-1.116 E R+0.281 F D I+0.583 R E M+\varepsilon \\
\text { Figure } 3
\end{gathered}
$$

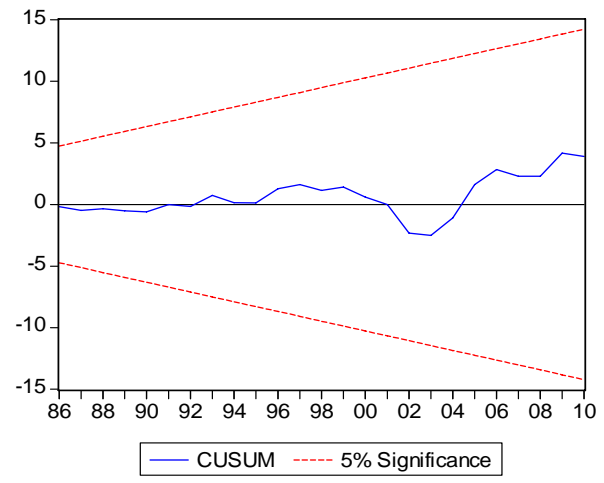

Figure 4

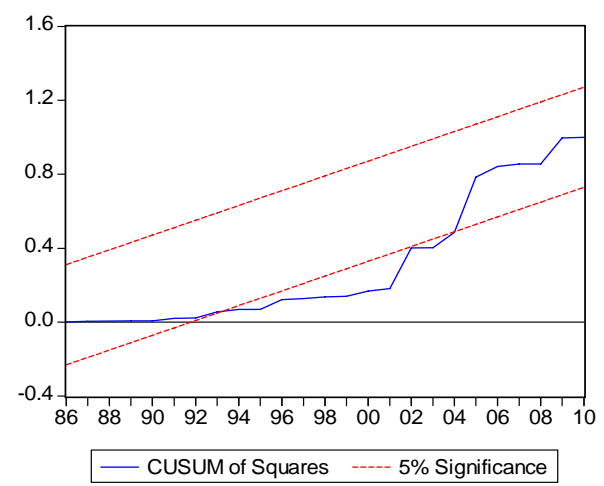

${ }^{24}$ Ray (2012), Mohammad (2010) 
Table 4.3.1: Co integration Test Results of TB Of India and Pakistan:

\begin{tabular}{|c|c|c|c|c|c|}
\hline Models & $\begin{array}{l}\text { Hypothesis } \\
\text { No. of CE(s) }\end{array}$ & $\begin{array}{l}\text { Trace } \\
\text { statistics }\end{array}$ & $\begin{array}{l}5 \% \\
\text { critical } \\
\text { values }\end{array}$ & $\begin{array}{l}\text { Max. } \\
\text { Eigen } \\
\text { value } \\
\text { statistics }\end{array}$ & $\begin{array}{l}5 \% \\
\text { critical } \\
\text { values }\end{array}$ \\
\hline \multirow{5}{*}{$\begin{array}{l}\text { Model } \\
\text { TB }_{\text {PAK }}\end{array}$} & None & 142.7780 & 69.81889 & 0.958864 & 33.87687 \\
\hline & At Most 1 & 56.62477 & 47.85613 & 0.646117 & 27.58434 \\
\hline & At Most 2 & 28.57747 & 29.79707 & 0.441678 & 21.13162 \\
\hline & At Most 3 & 12.84137 & 15.49471 & 0.349181 & 14.26460 \\
\hline & At Most 4 & 1.244236 & 3.841466 & 0.045037 & 3.841466 \\
\hline \multirow{5}{*}{$\begin{array}{ll}\text { Model } 2 \\
\text { TB }_{\text {IND }}\end{array}$} & None & 170.9489 & 79.34145 & 0.978023 & 37.16359 \\
\hline & At Most 1 & 67.86997 & 55.24578 & 0.712232 & 30.81507 \\
\hline & At Most 2 & 34.23879 & 35.01090 & 0.518195 & 24.25202 \\
\hline & At Most 3 & 14.52296 & 18.39771 & 0.385256 & 17.14769 \\
\hline & At Most 4 & 1.386142 & 3.841466 & 0.050043 & 3.841466 \\
\hline
\end{tabular}

Table 4.3.1 reports rejection of null hypothesis at five percent level of significance, for both the Trace statistics and the maximum eigen value statistics, in favour of alternative that there are two cointegration vectors for both models. Therofore, based on the results it is concluded that long run relationship exists between the considered variables.

\section{Granger Causality Test}

In this section Granger casuality analysis has been performed to find the causal relationship among the variables GDP, FDI, Remittances, ER and trade balance. Standard Granger (1969) structure has been used. Jones (1989) expresses that ad hoc selection method for lag length in Granger casulity is better than some of the statistical method used to determine optimal lag. Consequetly two lag lenghts are assumed for the whole model. The results of Granger causality are represented below.

TABLE:4.4.1

Model of TB of India

\begin{tabular}{llll}
\hline \hline Null Hypothesis: & Obs & F-Statistic & Prob. \\
\hline \hline FDI does not Granger Cause TB & 28 & $\begin{array}{l}9.58096 \\
0.0009\end{array}$ & 0.6906 \\
TB does not Granger Cause FDI & 0.37616 & 0.6906 & \\
\hline \hline
\end{tabular}


Business Review - Volume 9 Number 1

\begin{tabular}{llll}
\hline GDP does not Granger Cause TB & 28 & 5.13649 & 0.0143 \\
TB does not Granger Cause GDP & 2.48630 & 0.1053 & \\
\hline \hline ER does not Granger Cause TB & 28 & 10.4130 & 0.0006 \\
TB does not Granger Cause ER & 2.85019 & 0.0784 & \\
\hline \hline REMI does not Granger Cause TB & 28 & 4.83781 & 0.0176 \\
TB does not Granger Cause REMI & 3.12830 & 0.0628 & \\
\hline \hline
\end{tabular}

Source: Author's estimations.

Note: Lag length in each case is two as per Akaike Information Criteria(AIC). Critical values for F-statistics can be found in Gujrati (1995),p.814.

From the first table 4.4.1 it is clear that the GDP , REM and ER have a bidiretional causality with respect to trade balance. However unidirectional causality is found in case of FDI(from FDI to TB).

TABLE:4.4.2 Model Of TB of Pakistan

\begin{tabular}{lccl}
\hline \hline Null Hypothesis: & Obs & F-Statistic & Prob. \\
\hline \hline FDI does not Granger Cause TB & 28 & 7.65896 & 0.0028 \\
TB does not Granger Cause FDI & & 0.53189 & 0.5945 \\
\hline \hline GDP does not Granger Cause TB & 28 & 7.78466 & 0.0026 \\
TB does not Granger Cause GDP & & 1.25424 & 0.3041 \\
\hline \hline ER does not Granger Cause TB & 28 & 9.53875 & 0.0010 \\
TB does not Granger Cause ER & & 0.19456 & 0.8245 \\
\hline \hline REMI does not Granger Cause TB & 28 & 1.71046 & 0.2030 \\
TB does not Granger Cause REMI & & 1.11087 & 0.3463 \\
\hline \hline
\end{tabular}

Source: Author's estimations.

Note: Lag length in each case is two as per Akaike Information Criteria(AIC). Critical values for F-statistics can be found in Gujrati (1995),p.814.

In the table 4.4.2 there is no bidirectional causality between any of the variables, however uni directional causalaity exists from FDI, GDP and ER . this means that all of these variables can be used to predict the TB. 


\section{Conclusion \& Recommendation}

\section{Conclusion}

A number of researches have been performed on trade balance and its determinants, but few have conducted a comparison between two neighboring countries. This study investigates and compares the determinants of the trade balances of Pakistan and India. In this research the impact of gross domestic product (GDP), foreign direct investment (FDI), exchange rate (ER) and the remittances on the trade balance of India and Pakistan have also been considered. For this, time series data from 1981 to 2010 has been used. The results of the study are based on the regression analysis, Granger causality, and co integration. The results of regression analysis showed that the GDP of India and Pakistan both have significant positive impact on the balance of the trade, FDI has significant negative impact on TB of Pakistan and significant positive impact on the TB of India, this negative relation in case of Pakistan is due to multiple reasons, such as security concerns, political unrest, the different wars, corruption and improper utilization of labor and capital. ER has significant negative impact on both India and Pakistan's TB and remittances have significant negative impact for Pakistan and significant positive impact for the TB of India. Granger causality result showed bidirectional causal relation in Indian model, and uni directional causal relation in Pakistani model.

\section{Future Recommendations}

- It is recommended to policy makers that the local currency needs to be stronger in order to improve the trade balance of both the Pakistan and India.

- Government should impose heavy taxes on the import of luxury items so that the amount of remittances can be saved and need to motivate the people to use remittances in a productive way.

- We need to improve the quality of domestic productions so that use of foreign goods can be reduced.

- The outcome recommends that for Pakistan a more comprehensive research is required in order to identify the factors which are responsible for the negative effect of both FDI and Remittances on the trade balance. As comparing with India both these variables have shown a positive relationship, by conducting a more thorough research into this Pakistan can also use these two variables in its advantage.

\section{References}

Awan, A., Asghar, N., and Rehman, H. U. (2011), The impact of exchange rate, fiscal deficit, and term of trade on external debt of Pakistan, "Australian Journal of Business and Management Research”, Vol. 1 (3), 10-24.

Babar, S. (2006), Determining Import Intensity of Exports for Pakistan. "SBP Working Paper", Working paper No. 15, 1-20.

Calderon, C., Chong, A., and Loayza, N. (1999), Determinants of current account deficits in developing countries, "Central Bank of CHILE, Working Papers", Working paper no 51 , 141.

Duasa, J. (2007), Determinants of Malaysian trade balance: An ARDL bound testing approach, “Journal Of Economic Cooperation”, Vol. 28 (3), 21-40.

Falk, M. (2008), Determinants of the Trade Balance in Industrialized Countries, "FIW Research Report”, Working paper No. 013, 1-25. 
Grube, B. T., and Samanta, S. K. (2003), Effects Of Exchange Rate Uncertanity On Mexican Foreign Trade, “The Multinational Business Review” , Vol. 11 (2), 1-15.

Lal, A. K., and Lowinger, T. C. (2002), Nominal Effective Exchange Rade and Trade Balance Adjustments In South Asian Countries, “Journal Of Asian Economies”, Vol. 13, 371-383.

Mohammad, S. D. (2010), Determinant of Balance of Trade: Case Study of Pakistan, “European Journal of Scientific Research”,Vol. 41 (1), 13-20.

Mohammad, S. D., and Hussain, A. (2010), The Role of Exchange Rate on Balance of Trade: Emperical from Pakistan, “European Journal of Social Sciences”, Vol. 14 (1), 150-156.

Ray, S. (2012), An Analysis of Determinants of Balance of Trade in India, "Research Journal of Finance and Accounting”, Vol. 3 (1), 73-83.

Shahbaz, M., Abdul, J., and Islam, F.(2010). Real Exchange Rate Changes and Trade Balance in Pakistan.Munich Personal RePEcArchive , 1-18.

Stucka, T. (2004), The Effects of Exchange Rate Change on the Trade Balance in Croatia, “IMF Working Paper”, WP No./04/65, 1-29.

Waliullah, Kakar, M. K., Kakar, R., and Khan, W. (2010), The Determinants of Pakistan’s Trade Balance: An ARDL Co integration Approach, “The Lahore Journal of Economics”, Vol. 15 (1), 1-26.

Zhung, R., Koo, W. W., and Mattson, J. W. (2007), Determinants of the U.S. Trade Balance in Consumer-Oriented Agricultural Products, "Agribusiness \& Applied Economics Report" WP No. 607, 1-17.

Those things that hurt, instruct.

Benjamin Franklin 